\title{
AKTY STRZELISTE JAKO WYRAZY WIARY I POBOŻNOŚCI CHRZEŚCIJAŃSKIEJ
}

Wydany przed laty watykański Enchiridion indulgentiarum ${ }^{2}$ w swoich Dodat$k a h^{3}$ zamieścił m.in. stosowne uwagi odnośnie do aktów strzelistych, tytułując je: Pobożne wezwania. Najpierw dokument w trzech punktach przedstawia objaśnienia ogólne, dotyczące pobożnościowych inwokacji, następnie zaś przytacza szereg ich przykładów, które - według dokumentu - są ,przyjęte zwyczajowo"4. Zgodnie z Enchiridion indulgentiarum akt strzelisty nie jest traktowany jako dzieło odpustowe „samo w sobie”s, lecz jako jego dopełnienie. Poprzez pobożną inwokację „,wierny z pokorną ufnością wznosi swoją myśl do Boga w czasie wypełniania swoich obowiązków życiowych i znoszenia przeciwności życiowych"6. Ponadto dokument podkreśla, że „pobożne wezwanie uzupełnia wzniesienie myśli do Boga i razem z nim stanowi jakby drogocenny kamień, który zostaje włączony w powszednie życie" "7. Innymi słowy człowiek wierzący jako istota psychofizyczna swoje duchowe przeżycia wewnętrzne ujawnia w zewnętrznych formach czci i uwielbienia Boga ${ }^{8}$, do których zasadnie należą również pobożne wezwania, trafnie określone w języku polskim jako akty strzeliste ${ }^{9}$.

Niniejsza refleksja na temat aktów devotio indywidualnej ma zatem na celu nie tylko pogłębione studium tychże, ale nade wszystko pragnie ukazać dogłębną relację

\footnotetext{
${ }^{1}$ Ks. Jan Szczych, dr liturgiki, wykładowca w Wyższym Seminarium Duchownym w Tarnowie, proboszcz parafii Lubień Wielki w archidiecezji lwowskiej.

${ }^{2}$ Enchiridion indulgentiarum. Normae et concessiones, Città del Vaticano 2004. Polski przekład został zatwierdzony przez Penitencjarię Apostolską w 2006 r. i wydany w Katowicach pt. Wykaz odpustów. Normy i nadania.

${ }^{3}$ Wykaz odpustów. Normy i nadania, Katowice 2012, s. 85-88.

${ }^{4}$ Tamże, s. 86.

${ }^{5}$ Tamże, s. 85.

${ }^{6}$ Tamże.

${ }^{7}$ Tamże.

${ }^{8}$ Zob. T. Sinka, Liturgika, Kraków 1997, s. 19.

${ }^{9}$ Zob. J. Szczypta, Modlimy się aktami strzelistymi, Sandomierz 2007, s. 8.
} 
między pobożnością chrześcijanina, wyrażającą się poprzez wewnętrzne i zewnętrzne akty jego kultu a postawą wiary w zbawiającą bliskość Boga i Jego świętych.

\section{UJĘCIE HISTORYCZNO-LITURGICZNE}

Chrześcijańska doktryna ukazuje modlitwę jako „zwrócenie się człowieka do Boga" w odpowiedzi na Jego inicjatywę miłości (zob. Katechizm Kościoła katolickiego, 2567). Na modlitwie więc człowiek wierzący wznosi swą duszę do Boga, potwierdzając w ten sposób nie tylko swoją zależność od Stwórcy, ale także wyrażając własną miłość względem zawsze wiernego Boga. „W Nowym Testamencie wzór doskonałej modlitwy stanowi synowska modlitwa Jezusa. Zanoszona często w samotności i w ukryciu, modlitwa Jezusa wyraża miłujące przylgnięcie do woli Ojca" (Katechizm Kościoła katolickiego, 2620). Codzienna ewangelizacyjna aktywność Chrystusa „łączyła się ściśle z modlitwą, nawet więcej: ona jakby z modlitwy płynęła"10. Swoją postawą oraz bezpośrednim nauczaniem Jezus formował swoich naśladowców, by modlili się ,,sercem czystym, z żywą i wytrwałą wiarą, z synowską śmiałością" (Katechizm Kościoła katolickiego, 2621). Zbawiciel jednoznacznie „podkreślał konieczność modlitwy pokornej, czujnej, ustawicznej i ufnej w dobroć Ojca, ożywionej dobrą intencją i pełnej szacunku w obliczu Boga" ${ }^{11}$.

Jezusowe nauczanie na temat modlitewnej relacji człowieka z Bogiem ma swoje bezpośrednie odniesienie do Tradycji i mentalności żydowskiej, Żydzi bowiem byli ludem rozmodlonym ${ }^{12}$. „Pobożny Izraelita rozpoczynał dzień od dziękczynienia i uwielbienia Boga i taka duchowa postawa towarzyszyła każdej jego codziennej czynności. W ten sposób każda chwila jego życia, radosna czy smutna, była czasem wyrażania chwały Boga, błagania lub żalu za popełniane winy" ${ }^{13}$. Także apostołowie jako pobożni Izraelici modlili się codziennie i praktykowali indywidualną pobożność. Jakkolwiek ,dane biblijne nie dostarczają nam żadnych bliższych informacji na temat modlitwy pierwszych chrześcijan: zarówno tej wspólnotowej, jak i tej prywatnej”, to jednak przypuszcza się z dużym prawdopodobieństwem, że ,judeochrześcijanie generalnie podtrzymywali żydowskie zwyczaje modlitewne"14, mając przy tym głęboką świadomość, iż ich modlitwa jest skierowana do Boga Ojca w imię Jezusa (zob. J 16, 23-24; 1 Kor 1, 2; Kol 3, 17) ${ }^{15}$.

${ }^{10}$ Ogólne Wprowadzenie do Liturgii godzin, w: Liturgia godzin, t. I, Poznań 1982, s. 25, nr 4.

${ }^{11}$ Tamże, s. 26, nr 5.

${ }^{12}$ Zob. La celebrazione nella Chiesa, ed. D. Borobio, t. 1: Liturgia e sacramentaria fondamentale, Leumann (Torino) 1992, s. 64

${ }^{13}$ Kongregacja ds. Kultu Bożego i Dyscypliny Sakramentów, Dyrektorium o pobożności ludowej i liturgii, Poznań 2003, s. 29-30, nr 23.

${ }^{14}$ D. Brzeziński, Publiczna modlitwa Kościoła w starożytności chrześcijańskiej, w: Mirabile laudis canticum. Liturgia godzin: dzieje i teologia, red. H. J. Sobeczko, Opole 2008, s. 68.

${ }^{15}$ Szerzej nt. modlitewnych praktyk pierwszych wyznawców Chrystusa zob. R. F. Taft, La liturgia delle ore in oriente e occidente, Roma 2001, s. 20-31. 
Od samego początku w kręgu Jezusowych uczniów można zauważyć - oprócz praktykowania tradycyjnego kultu judaistycznego - wspólistnienie publicznych bądź półpublicznych form ich chrześcijańskiej liturgii (zob. Dz 2, 42.46; 12, 5; 20, 7.36; 21, 5; 1 Kor 11, 18; por. 16,2) oraz wyrazów ich pobożności prywatnej, indywidualnej, wynikającej z osobistej duchowej więzi każdego wierzącego z Chrystusem Panem (zob. Mt 6, 5-13; Dz 10, 9; por. Kol 4, 2). Dlatego też ,ewangelie i wszystkie inne pisma Nowego Testamentu zawierają wezwania kierowane do Chrystusa i powtarzane jako akty strzeliste wiernych poza tekstami liturgicznymi... Wystarczy przypomnieć takie wezwania biblijne, jak: «Jezu, Synu Dawida, ulituj się nade mną» (Łk 18, 38); «Panie, jeśli chcesz, możesz mnie oczyścić» (Mt 8, 2); «Jezu, wspomnij na mnie, gdy przyjdziesz do swego królestwa» (Łk 23, 42); «Pan mój i Bóg mój» (J 20, 28); «Panie Jezu, przyjmij ducha mojego» (Dz 7, 59). Na fundamencie tych wezwań powstały niezliczone modlitwy, kierowane do Chrystusa" 16 , kształtujące na przestrzeni wieków chrystocentryczną pobożność chrześcijańskich wiernych. Słusznie zatem uważa się przytoczone biblijne wezwania adresowane do Chrystusa za pierwowzór aktów strzelistych, które na różny sposób i w odmiennych formach są praktykowane w prywatnej pobożności wierzących. Wymienione wołania pozostają też trafnym przykładem realizowania $\mathrm{w}$ chrześcijańskim życiu drugiego przykazania Bożego, zobowiązującego wierzących do wzywania imienia Pańskiego „tylko po to, by je błogosławić, wychwalać i uwielbiać" (Katechizm Kościoła katolickiego, 2143).

Pobożne inwokacje wiernych ,wywodzą się z wewnętrznej postawy wiary” i jako takie stanowią ,zewnętrzne praktyki pobożności"' ${ }^{17}$. Człowiek wierzący bowiem, stając się w pełni uczniem Chrystusa i członkiem Kościoła, nie wyzbywa się naturalnych cech własnej indywidualności, która ipso facto staje się konkretnym wyrazem jego chrześcijańskiej tożsamości ${ }^{18}$. Wyznawca Chrystusa, będąc zobowiązanym do uczestnictwa w oficjalnej liturgii Kościoła, jak też będąc powołanym do modlitwy w postaci nabożeństwa ludu chrześcijańskiego o charakterze prywatnym lub wspólnotowym, wyraża także osobistą, indywidualną łączność z Bogiem poprzez wznoszenie ku Niemu myśli i pragnień swojego serca. W ten sposób prywatny pobożnościowy akt chrześcijanina, wysławiany w stosownych okolicznościach i atmosferze duchowej, jest ,jakby solą, która odpowiednio przyprawia [jego] działanie"19 i jednocześnie znaczącym wyrazem wysławiania Boga i odczuwania Jego bliskości.

Jak podkreśla Enchiridion indulgentiarum, ,akt strzelisty może być bardzo krótki, wyrażony jednym lub kilkoma słowami albo uczyniony w myśli’’20. W perspektywie takiego niejako technicznego przedstawienia kwestii modlitwy stricte prywatnej dostrzec można różnice między omawianymi inwokacjami a powszechnie

\footnotetext{
${ }^{16}$ Dyrektorium o pobożności ludowej i liturgii, dz. cyt., s. 30, nr 23.

${ }^{17}$ Tamże, s. 17, $\mathrm{nr} 8$.

${ }^{18}$ Zob. M. Righetti, Storia liturgica, t. I, Milano 1998, s. 17.

${ }^{19}$ Wykaz odpustów. Normy i nadania, dz. cyt., s. 85.

${ }^{20}$ Tamże.
} 
uznanymi przez Kościół formami modlitwy liturgicznej czy nabożeństwami związanymi z oficjalną liturgią Kościoła. Jeśli publiczne lub prywatne formy pobożności chrześcijańskiej, nie będąc wprost częścią liturgii, „zgadzają się z nią, respektując jej ducha" i z niej „w pewnej mierze czerpią swą inspirację"21, prowadząc do niej wiernych, to podobnie powyższe kryteria odnoszą się również do aktów strzelistych, które „swoją inspirację winny czerpać z Pisma Świętego, liturgii, Ojców i nauczania Kościoła oraz zgadzać się z jego wiarą"22. W ten sposób zakorzenione w bogatym dziedzictwie Kościoła indywidualne wyrazy pobożności wiernych, będące wyraźną ekspresją ich osobistej relacji z Bogiem i świętymi, naturalnie wpisują się w szeroki wachlarz i obszar pobożności eklezjalnej ${ }^{23}$.

\section{AKTY STRZELISTE „POTWIERDZONE DŁUGĄ PRAKTYKĄ WIERNYCH”}

W rozumieniu Enchiridion indulgentiarum spośród aktów strzelistych pierwszeństwo ma takie wezwanie, „które spontanicznie wypływa $\mathrm{z}$ wnętrza lub jest wybierane z szeregu tych, jakie zostały potwierdzone długą praktyką wiernych"24. Oba przywołane typy pobożnościowych inwokacji można bez cienia wątpliwości połączyć jednym mianownikiem impulsu z potrzeby serca: wypływają ,z wnętrza” i odzwierciedlają moc wiary osoby modlącej się ${ }^{25}$. Wtedy też jasno zostają połączone stan ducha, okoliczności życia i poziom wiary chrześcijanina. Jeśli w pierwszym przypadku, gdy pobożne wezwanie jest wypowiadane spontanicznie, odruchowo czy samorzutnie, jego bezpośrednim autorem pozostaje sama osoba wierząca, to w drugiej kategorii aktów strzelistych człowiek zwracający sie do Boga czy świętych korzysta z dotychczasowej spuścizny kościelnej pobożności. Bezsprzecznie jednak obydwa sposoby odwoływania się do Bożej obecności lub do tajemnicy obcowania świętych - zarówno poprzez formy słowne, jak i te uczynione w myślach - pozostają świadomą oznaką Bosko-ludzkich relacji (por. Ef 6, 16).

$\mathrm{W}$ omawianym dokumencie zamieszczono szereg przykładów pobożnych wezwań, potwierdzonych „długą praktyką wiernych”26. Ich treść można zgrupować następująco:

${ }^{21}$ Dyrektorium o pobożności ludowej i liturgii, dz. cyt., s. 17, nr 7.

${ }^{22}$ Tamże, s. 22, nr 16.

${ }^{23}$ Por. A. J. Chupungo, Nozione di liturgia, w: Scientia liturgica, t. I, red. A. J. Chupungo, Casale Monferrato 1998, s. 23.

${ }^{24}$ Wykaz odpustów. Normy i nadania, dz. cyt., s. 85.

${ }^{25} \mathrm{~W}$ religijnym życiu chrześcijan nie jest też obcą praktyka, kiedy pobożne wezwania są wypowiadane bezmyślnie i odruchowo, tj. nadaremnie, nie stanowiąc żadnego przejawu ufnej modlitwy, kierowanej do Boga lub świętych, albo też dla potwierdzenia własnych prawdziwych lub fałszywych oświadczeń. Wówczas wypowiadana inwokacja przeczy drugiemu przykazaniu Bożemu, gdyż ,świętość imienia Bożego wymaga, by nie używać go do błahych spraw” (Katechizm Kościota katolickiego, 2155; zob. 2146). Zob. S. Olejnik, Teologia moralna, t. 5, Warszawa 1991, s. 96.

${ }^{26}$ Wykaz odpustów. Normy i nadania, dz. cyt., s. 85. 
- Wezwania proste, wyrażone jednym lub dwoma słowami. Należą do nich bezpośrednie zwroty do Boga lub Jezusa. Przywoływanie imion bożych z intencją oddania czci Stwórcy i Zbawicielowi odzwierciedla łączność człowieka wierzącego z Bogiem Ojcem, który ,jest Bytem duchowym, transcendentnym, wszechmocnym, wiecznym, osobowym, doskonałym" 27 , lub z Jezusem Chrystusem, który jako prawdziwy Bóg i prawdziwy człowiek jest jedynym Pośrednikiem między Bogiem i ludźmi (zob. 1 Tm 2, 5). Dla wiernego zatem „należyte, pełne czci wymawianie imienia «Bóg» lub «Jezus» jest hołdem składanym Bogu, przypomnieniem jego doskonałości, odwołaniem się do Jego potęgi i miłości”28.

- Akty pochwały i uwielbienia. Te pobożne wezwania, zawierające laudatio Dei, są traktowane jako „najwspanialsza modlitwa”29 chrześcijanina. Poprzez uwielbienie i pochwałę Boga człowiek wierzący ,wysławia Go dla Niego samego, oddaje $\mathrm{Mu}$ chwałę nie ze względu na to, co On czyni, ale dlatego że ON JEST" (Katechizm Kościoła katolickiego, 2639). Najbardziej popularnym i nierzadko używanym aktem uwielbienia jest tradycyjne chrześcijańskie zawołanie: „Niech będzie pochwalony Jezus Chrystus!"’30. Poprzez te słowa wierny z jednej strony uzewnętrznia swoją wiarę w osobę Jezusa Chrystusa, oddając pochwałę Jego imieniu (zob. Dz 4, 12), z drugiej zaś, kierując się życzliwością ku współwyznawcom, tym pozdrowieniem wyprasza im Jego boską łaskawość.

- Oznaki wiary, nadziei i miłości, będące naturalną konsekwencją trzech cnót teologalnych, „których początkiem, motywem i przedmiotem bezpośrednim jest sam Bóg”’31. Ponieważ cnoty teologalne ,są wszczepione przez Boga w dusze wiernych, by uzdolnić ich do działania jako dzieci Boże i do zasługiwania na życie wieczne" (Katechizm Kościoła katolickiego, 1813), wypływające z ich praktykowania akty pobożności osób wierzących stanowią potwierdzenie obecności i działania w nich samego Ducha Świętego ${ }^{32}$. Wewnętrzne przyznanie się człowieka do wiary w Boga i Bogu, pokładanie głębokiej ufności w Bożych obietnicach, wreszcie umiłowanie Go całym sercem przy jednoczesnym miłowaniu siebie i bliźnich otrzymują swoje wyraźne uzewnętrznienie i afirmację m.in. w indywidualnej praktyce pobożnych wezwań dotyczących wiary, nadziei i miłości.

- Akty dziękczynienia, formułujące ludzką wdzięczność za otrzymane Boże dary (zob. 1 Tes 5, 18). „Każde wydarzenie i każda potrzeba mogą stać się dla chrześcijanina motywem i przedmiotem dziękczynienia" "33. Postawa wdzięczności za bycie obdarowanym pozostaje niekwestionowanym dowodem świadomej wiary

${ }^{27}$ Kompendium Katechizmu Kościoła katolickiego, Kielce 2005, s. 34, nr 40.

${ }^{28}$ S. Olejnik, Teologia moralna, dz. cyt., s. 77.

${ }^{29}$ Por. M. Kunzler, Liturgia Kościoła, Poznań 1999, s. 520.

${ }^{30}$ Szerzej nt. aklamacyjnych formuł uwielbienia zob. M. Righetti, Storia liturgica, dz. cyt., t. I, s. $208-210$.

${ }^{31}$ Kompendium Katechizmu Kościoła Katolickiego, dz. cyt., s. 129, nr 384.

${ }^{32}$ Zob. Tamże.

${ }^{33}$ Tamże, s. 181, nr 555. 
chrześcijanina, który zarówno „w duchu”, jak i słowami jednoznacznie wyznaje i potwierdza, że „to wszystko, czym jesteśmy i co posiadamy, pochodzi od Stwórcy” (por. Katechizm Kościoła katolickiego, 224).

- Akty prośby, w których wierzący przedstawia Bogu osobiste cele i pragnienia „W celu osiągnięcia ich spełnienia"34. Błagalne wezwania wyrażają również świadomość relacji człowieka z Bogiem: ,jako stworzenia nie decydujemy o naszym początku, nie jesteśmy panami naszego losu; nie stanowimy sami dla siebie celu; ponadto jako chrześcijanie wiemy, że - będąc ludźmi grzesznymi - odwracamy się od naszego Ojca. Prośba jest już powrotem do Niego" (Katechizm Kościoła katolickiego, 2629). Potrzebujący zatem ,jako istota skończona” świadomie „staje przed nieskończonym i nieograniczonym Bogiem" i poprzez pobożne akty prośby błaga Go „o przezwyciężenie swojej nędzy, o udział w bezgranicznej pełni życia w Bogu”35.

- Akty przebłagania, kiedy to wierny wyznaje świętość Boga i jednocześnie uznaje własną grzesznośćc ${ }^{36}$. Wołanie o przebaczenie, wypowiadane przez człowieka wierzącego, ,jest pierwszym dążeniem modlitwy prośby" (Katechizm Kościoła katolickiego, 2631). Wierny, znajdując się w kondycji własnego bólu duchowego, spowodowanego przez grzech i ludzką niedoskonałość, szczerze i w pokorze serca zwraca się do Boga, pragnąc naprawić spowodowaną zniewagę w nadziei na otrzymanie upragnionego przebaczenia.

- Wezwania maryjne, ukazujące dziecięce relacje między modlącym się a osobą Najświętszej Maryi Panny. Chrześcijanie są głęboko przeświadczeni, że Maryja, będąc Matką Bożego Syna (zob. Łk 1, 26-38.43), z Jego ustanowienia stała się także ich Matką (zob. J 19, 25-27). Dlatego uznając Matkę Najświętszą za skuteczną u Boga Orędowniczkę, w indywidualnych aktach pobożności przyzywają Jej imienia, by w dziecięcym zaufaniu i oddaniu dzielić z Nią swoje bóle i radości ${ }^{37}$.

Opisane powyżej akty strzeliste, potraktowane według poszczególnych ich kategorii, odzwierciedlają bogatą przestrzeń modlitewnych form Kościoła, które konsekwentnie - i to bez żadnej przesady - oraz skutecznie wpłynęły na indywidualną pobożność wierzących. Pobożne wezwania pojedynczych wiernych, trwale zakorzenione bądź w Piśmie Świętym, bądź Tradycji Kościoła, poprzez ich popularne

${ }^{34}$ S. Olejnik, Teologia moralna, dz. cyt., s. 64. Według tego autora, „modlitwa prośby nie jest czymś w rodzaju powiadomienia Boga o nie znanych $\mathrm{Mu}$ jakoby sprawach życia ludzkiego. Nie jest to także usiłowanie zmiany odwiecznych wyroków Opatrzności ani tym bardziej przynaglania Boga jakoby obojętnego czy niełaskawego dla człowieka. Człowiek modli się, błagając Boga, aby raczył urzeczywistnić to, co odwiecznie postanowił w swoich planach, ale mając na uwadze tę prośbę człowieka" (tamże).

${ }^{35}$ M. Kunzler, Liturgia Kościoła, dz. cyt., s. 521.

${ }^{36}$ Zob. J. Castellano, Preghiera e liturgia, w: Nuovo Dizionario di Liturgia, a cura di D. Sartore, A. M. Triacca, Cinisello Balsamo (Milano) 1995, s. 1029.

${ }^{37}$ Spośród wielu form pobożności maryjnej wyróżnia się m.in. osobiste powierzenie się Maryi Pannie. Zob. Dyrektorium o pobożności ludowej i liturgii, dz. cyt., s. 144-145, nr 204. 
używanie stały się więc niekwestionowanym wymiarem powinności modlitwy każdego chrześcijanina (zob. 1 Tes 5, 17).

\section{3. „WEZWANIA PRZYJĘTE ZWYCZAJOWO”}

W następnej części objaśnienia na temat pobożnych wezwań Enchiridion indulgentiarum przytacza 37 inwokacji, które klasyfikuje jako „przyjęte zwyczajowo”, przy jednoczesnym dopowiedzeniu, że są one podane jedynie „przykładowo"38. Osiem modlitewnych aktów stanowi bezpośrednie cytaty z Pisma Świętego, z kolei pozostałe wezwania są wyrazem wielowiekowego dziedzictwa Kościoła. Dokument, podając znane przykłady pobożnościowych aktów, zaznacza także, że w poszczególnych językach narodowych istnieją jeszcze ,inne wezwania”, przytoczone w „licznych modlitewnikach" wydanych na użytek wiernych w Kościołach partykularnych ${ }^{39}$.

Przytoczone w Enchiridion indulgentiarum zwyczajowe akty strzeliste (usu receptae) tworzą swoistą modlitewną mozaikę, której poszczególne elementy mogą śmiało ukazać głębokie życie duchowe konkretnego chrześcijanina. Klasyfikacja aktów strzelistych, „przyjętych zwyczajowo”, przedstawia się zatem następująco:

- Dwa wezwania trynitarne, w których wierny błogosławi i uwielbia Trzy Osoby Boskie. Pierwszy tego typu akt strzelisty ma charakter życzeniowy i dotyczy błogosławienia Trójcy Świętej, natomiast drugie wezwanie jest już wyraźną formułą doksologiczną, określaną także jako „doksologia krótka”"40, w której wierny oddaje chwałę równorzędnie Ojcu i Synowi, i Duchowi Świętemu. Dla człowieka ochrzczonego w imię trzech Osób Boskich „tajemnica Trójcy Świętej stanowi centrum wiary i życia chrześcijańskiego" (Katechizm Kościoła katolickiego, 234), dlatego też pobożna inwokacja ku czci Osób Boskich wyraża „prawdziwy dialog między Bogiem i człowiekiem przez Chrystusa w Duchu Świętym" "41. Chrześcijanin zatem, uwielbiając Trójjedynego Boga, chętnie poddaje się Jego opatrzności i dziękuje za dzieło stworzenia, odkupienia i uświęcenia, którego ostatecznym celem ,jest wejście stworzeń do doskonałej jedności Trójcy Świętej” (Katechizm Kościoła katolickiego, 260).

- Wotania odnoszace sie do Boga Ojca, będące przejawem ludzkiej wrażliwości na misterium Bożego ojcostwa ${ }^{42}$; większość z przytoczonych wezwań ma pochodzenie biblijne. Przyzywając na modlitwie „swojego Boga” (por. Ps 143, 10) albo za przykładem konającego Chrystusa (zob. Łk 23, 46), oddając się całkowicie Ojcu, pobożny chrześcijanin potwierdza w ten sposób swoje wyniesienie do stanu przybranych synów (zob. Rz 8, 15; Ga 4, 5-7). Ponieważ dzięki Chrystusowemu misterium

\footnotetext{
${ }^{38}$ Wykaz odpustów. Normy i nadania, dz. cyt., s. 86-88.

${ }^{39}$ Tamże, s. 86, przypis 3.

${ }^{40}$ W. Niedźwiecki, Maty Stownik Liturgiczny, Toruń 2003, s. 37.

${ }^{41}$ Dyrektorium o pobożności ludowej i liturgii, dz. cyt., s. 65, nr 79.

${ }^{42}$ Zob. tamże.
} 
odkupienia „wzywanie Boga nie jest [już] obwarowane tak surowymi przepisami ceremoniału jak w Starym Testamencie"43, dlatego modlący się bezpośrednio do Boga Ojca bezsprzecznie doświadczają, iż nie są już „obcymi i przychodniami, ale współobywatelami świętych i domownikami Boga" (Ef 2, 19).

- Inwokacje ku czci Jezusa Chrystusa, których Enchiridion indulgentiarum przytacza najwięcej, co z kolei uzasadnia stwierdzenie, że „,pobożność ludowa koncentruje się chętnie na osobie Chrystusa, Syna Bożego i Zbawiciela człowieka"44. Przywoływanie imienia Jezus w chrześcijańskiej codzienności jest bezpośrednim odwołaniem się do Jego Osoby i odkupieńczej działalności ${ }^{45}$. Gdy na modlitwie jest mowa o Jezusie Chrystusie, wówczas wierzący może śmiało wyakcentować wiele ujęć bądź przejawów tej samej prawdy wiary ${ }^{46}$. W tej perspektywie należy zatem tłumaczyć sporą liczbę wezwań Pańskich, jak też rozważać ich tematyczną różnorodność.

Na szczególne wyróżnienie zasługują takie modlitewne akty, które w swej treści zawierają bezpośrednie odwołanie się do Męki Jezusa, oraz te odnoszące się do Bożego Serca (Enchiridion podaje ich aż pięć). W pierwszej kategorii omawianych wezwań wiodącą ideą pozostaje temat krzyża, z kolei modlitewne inwokacje do Serca Jezusa wyrażają wiarę i ufność modlącego się w nieskończoną miłość Boga do każdego człowieka ${ }^{47}$.

Poprzez modlitewne wzywanie osoby Chrystusa ludzie wierzący nie tylko doznają pokrzepienia w swoich słabościach lub cierpieniach (zob. Mt 11,28), ale również dobrowolnie poddają się afirmacji Jego nauczania, by w ten sposób skutecznie doświadczyć Jego zbawiennych obietnic.

- Cztery wezwania skierowane do Świętej Rodziny, w których modlący się wymienia po imieniu Jezusa, Maryję i Józefa. Dla Chrystusowych wiernych Rodzina z Nazaretu stanowi „wzór życia”48 i wzajemnej miłości, dlatego adresowana do niej pobożna inwokacja wyraża dziecięcą postawę oranta, który chętnie zabiega o Jej skuteczne wstawiennictwo tak w życiu codziennym, jak i w perspektywie wieczności.

- Akty strzeliste odnoszące się do Matki Bożej, ukazujące synowskie przywiązanie oranta do Matki Jezusa. Wzywający pomocy Matki Bożej jest też świadom Jej

${ }^{43}$ S. Olejnik, Teologia moralna, dz. cyt., s. 77.

${ }^{44}$ Dyrektorium o pobożności ludowej i liturgii, dz. cyt., s. 65, $\mathrm{nr} 79$.

${ }^{45}$ Szerzej na ten temat zob. S. Ulanecki, Najsłodsze Imię Jezus $w$ trzydziestu jeden uwagach, przykładach, modlitwach i aktach strzelistych, Kraków 1917.

${ }^{46}$ Zob. M. Gronchi, Jezus - jedyny Syn Boga, w: Wierzę, red. J. Salij, Kielce 2012, s. 99-100.

${ }^{47}$ Według nauczania św. Bonawentury, Serce Jezusa „dlatego zranione zostało, byśmy przez ranę widzialną mogli wiedzieć niewidzialną ranę miłości”. S. Bonaventura, De vite mystica, cap. 3, w: Breviarium Romanum ex decreto SS. Concilii Tridentini restitutum S. Pii V Pontificis Max. jussu editum aliorumque Pontt. cura recognitum Pii Papae X auctoritate reformatum cum Psalterio secundum novam e textibus primigeniis interpretationem latinam Pii Papae XII auctoritate edito, pars aestiva, editio X Taurinensis juxsta Typicam, Romae 1949, s. 339: in Festo Sacratissimi Cordis Jesu, in III Nocturno, Lectio IX.

${ }^{48}$ Mszat rzymski dla diecezji polskich, Poznań 2009, s. 37. 
niezwykłego zjednoczenia z Jej Bożym Synem, stąd w jednym z wezwań nie waha się prosić o Ich wspólne błogosławieństwo i wsparcie. Enchiridion indulgentiarum podaje ponadto osiem wezwań stricte maryjnych, skierowanych wprost do osoby Matki Najświętszej. Wierzący przyzywa Maryję, używając Jej różnych tytułów: Panna święta, Matka Bolesna, Królowa, Niepokalanie poczęta oraz Zawsze Dziewica, a w jednej inwokacji bezpośrednio odwołuje się do Serca Maryi Panny.

Ogólnie wspólnym mianownikiem maryjnych aktów strzelistych jest prośba potrzebującego o modlitwę Matki Bożej, wyraźnie uwypuklająca też jej aspekt eklezjalny: módl się za nami. To we wspólnocie Kościoła wierzący uznaje w osobie Matki Najświętszej swoją Matkę, która „wyniesiona do niebieskiej chwały, otacza macierzyńską miłością” każdego członka Kościoła pielgrzymującego, ,aż nadejdzie pełen blasku dzień Pański" ${ }^{49}$.

- Wezwanie dotyczace świętych, gdzie pobożna osoba uprasza wstawiennictwa wszystkich zbawionych obu płci. W treści wezwania adresaci są nazwani Świeci $i$ Święte Boże, gdyż to wyłącznie Pan Bóg jest ,,jedynym źródłem świętości" ${ }^{50}$ odkupionych. Dla oranta wstawiennicza rola świętych pozostaje wyrazem jego wiary w tajemnicę „świętych obcowania”. Obdarzeni już zasłużoną nagrodą nieba, Wszyscy Święci i Święte z jednej strony są dla wiernych wzorem dla naśladowania, z drugiej zaś ,przyjęci do ojczyzny i znajdując się blisko przy Panu (por. 2 Kor 5, 8)" (KK 49), braterską troską skutecznie wspomagają pielgrzymujących ku niebu.

- Wezwanie za zmarlych. Wprawdzie pobożna inwokacja za zmarłych jest skierowana do Pana Jezusa i można by ją było zasadnie zakwalifikować jako „wezwanie Pańskie", niemniej jednak wyjątkowość jej treści skłania do osobnego wyszczególnienia tej modlitwy. Omawiane wezwanie nie zawiera w sobie wyrazu zmarli, ale prośba o „wieczne odpoczywanie” jednoznacznie interpretuje jego myśl przewodnią.

„Dzięki Chrystusowi śmierć chrześcijańska ma sens pozytywny” (Katechizm Kościoła katolickiego, 1010), stąd też modlitwa za zmarłych jest dla wierzących przejawem communio trzech stanów Kościoła (zob. Katechizm Kościoła katolickiego, 958-959). Prosząc Jezusa o wieczny odpoczynek dla zmarłych, wierny modli się, by otrzymali „świętość konieczną do wejścia do radości nieba” (Katechizm Kościoła katolickiego, 1030).

Akty strzeliste, które Enchiridion indulgentiarum określa jako „przyjęte zwyczajowo", pozostają niekwestionowanym świadectwem wiary uczniów Chrystusa. Dokonane wyżej posegregowanie omawianych wezwań według różnorodności ich adresatów obrazuje nie tylko pobożność indywidualną wierzącego, ale ukazuje ponadto, jak głęboką może być świadomość wydarzeń zbawczych modlącej się osoby. Szerokie spektrum pobożnościowego ujęcia historii zbawienia oraz prawd wiary, praktykowane na przestrzeni dziejów Kościoła i zwięźle zaprezentowane

49 Tamże, s. 74*.

${ }^{50}$ Por. Tamże, 251'. Zob. też T. a Kempis, O naśladowaniu Chrystusa, Kraków 1981, s. 164 165. 
w omówionych inwokacjach, dla człowieka wierzącego może stanowić swoisty zarys życiowego credo, przy jego jednoczesnej aplikacji życiowej.

\section{KONKLUZJA: KU POGŁĘBIONEJ RELACJI Z BOGIEM}

Pogłębione studium pobożnych inwokacji dokonane na kanwie Enchiridion indulgentiarum przedstawione jest $\mathrm{w}$ doktrynalnym i praktycznym kontekście nauki o odpustach. Jak już wspomniano, pobożne wezwanie, ,choćby tylko wewnętrzne” stanowi dopełnienie osobnego dzieła odpustowego, kiedy to wierzący „w wykonywaniu swoich obowiązków i znoszeniu przeciwności życiowych z pokorą i ufnością skieruje swoją myśl do Boga"51, zyskując ewentualnie odpust cząstkowy. W ten sposób Kościół ,prowadzi wiernych jakby za rękę do wypełniania Chrystusowego polecenia, że mianowicie «zawsze powinni się modlić i nie ustawać» (Łk 18, 1), a jednocześnie kieruje się do nich usilną zachętę, żeby każdy tak wypełniał swoje obowiązki, by zachować jedność z Chrystusem i w niej wzrastać" ${ }^{52}$.

Akty strzeliste ponadto wyrastają z praktyk pobożności ludowej, która „nosi w sobie jakiś głód Boga, jaki jedynie ludzie prości i ubodzy duchem mogą odczuwać"53. Dlatego pobożne wezwania pozostają wyrazem autentycznego ducha chrześcijańskiego, kiedy to modlący się wchodzi w zażyłość ze światem nadprzyrodzonym, a to z kolei pomnaża uświęcające skutki duchowej postawy oranta.

Pobożne inwokacje stanowią dla wierzących swoistą oznakę czy też sposób ich bycia $\mathrm{w}$ obecności Boga, a częstokroć powtarzane stają się jakby naczyniami, do których wlewa się obfitość ludzkiego serca ${ }^{54}$. Wobec tego, akt strzelisty z jednej strony wyraża duchowy żar modlącego się, a z drugiej zaś, zachowując prostotę i wyrazistość wymowy potwierdza głębię chrześcijańskiej ufności. Praktykowane „,akty strzeliste i pobożne wezwania rozpalają życie duchowe, podsycają je jak drewienka dokładane do ognia. Poprzez ich częste odmawianie ognisko łask Bożych płonie w duszy ludzkiej nieustannym płomieniem"s5 , dlatego takie wyrazy pobożności nie reprezentują jakiejś magii słów lub czystego sentymentalizmu, lecz są dowodem ufnej wiary chrześcijanina, ubranej w szatę słowną w konkretnych okolicznościach jego bytowania (por. Ef 6, 18).

W myśl Konstytucji o liturgii świętej Soboru Watykańskiego II życie duchowe osób wierzących „nie ogranicza się do udziału w samej tylko liturgii” (KL 12), dlatego praktykowanie w obrębie kultu Kościoła pobożności prywatnej w postaci modlitewnych wezwań i krótkich oracji pozostaje dla wierzącego owocnym sposobem wychwalania Boga i odczuwania Jego bliskości.

\footnotetext{
${ }^{51}$ Wykaz odpustów. Normy i nadania, dz. cyt., s. 33.

52 Tamże.

${ }^{53}$ Dyrektorium o pobożności ludowej i liturgii, dz. cyt., s. 18, nr 9.

${ }^{54}$ Por. R. Guardini, Lo spirito della liturgia. I santi segni, Brescia 2000, s. 30, przypis 9.

${ }^{55}$ Por. J. Szczypta, Modlimy się aktami strzelistymi, dz. cyt., s. 10.
} 


\section{SŁOWA KLUCZOWE}

pobożne wezwanie, akt strzelisty, pobożność, modlitwa, wyraz wiary

\section{SUMMARY}

\section{Ejaculatory prayers (ejaculations) as an expression of christian faith and piety}

Enchiridion indulgentiarum of Vatican treats, among others, of prayers of aspiration (aspirations), commonly called ejaculatory prayers (ejaculations), which are complements to individual indulgences. According to the document, an ejaculatory prayer is usually very short, expressed verbally or as a thought and as such externalizes a Christian's internal attitude.

Among pious invocations, it is possible to distinguish prayers which spontaneously flow from within a believer's inside and those that have been confirmed by worshippers' long practice or are customarily acknowledged. A collection of these prayer formulas as well as reflection on their content shows not only a believer's individual piety but also portrays a praying person's depth of consciousness of salvational occurrences. Thus, aspirations, whilst preserving their simplicity and expressiveness of significance, become a believer's undisputed proof of faith and devotion.

\section{KEYWORDS}

prayer of aspiration, ejaculatory prayer, pious invocations, piety, devotion, prayer, expression of faith 
